KEMAS 15 (3) (2020) 344-355
Jttp://journal.unnes.ac.id/nju/index.php/kemas

\title{
Identification of Causes and the Existence of Mercury and Chromium in Sediment and Sea Water in Kendari Bay
}

\author{
Sri Damayanty ${ }^{\varpi}$, Muhammad Kamal, Arief Pawennari Muhammad \\ Public Health Department, Faculty of Health Science, Institut Teknologi dan Kesehatan Avicenna
}

\section{Article Info \\ Article History: \\ Submitted July 2019 \\ Accepted November 2019 \\ Published March 2020 \\ Keywords: \\ Mercury, chromium, water, \\ sediment, Kendari Bay \\ DOI \\ https://doi.org/10.15294/ \\ kemas.v15i3.19850}

\begin{abstract}
Kendari Bay is currently experiencing considerable physical pressure and pollution due to heavy metals. This study aims to determine the content of heavy metals mercury and chromium in sediment and seawater in Kendari Bay. This study uses an observational design with a descriptive approach. The study was conducted in April 2019 in five Port areas with three sampling points in each region. Samples taken are sediment and seawater. Samples taken were analyzed by the Atomic Absorption Spectrophotometry (AAS) method. The results show that all sampling points at five Ports have been contaminated with mercury and chromium in sediment and seawater. The levels of mercury and chromium have exceeded the quality standards stipulated by Minister of Environment Decree No. 51 of 2004. The highest levels of mercury and chromium in seawater and sediment are highest in the Dermaga Tempat Pendaratan Ikan (TPI). This is due to the dense traffic activity of fishing vessels, residential waste, Hospital waste, hospitality waste, tourist waste, paints on ships, oil spills, rust from shipwrecks, and heavy equipment activities from the construction of the Bahteramas Bridge or the Kendari Bay Bridge. Technology needs to control heavy metal contamination as well as policies and law enforcement regarding activities at sea that have the potential to pollute waters.
\end{abstract}

\section{Introduction}

The quality of the sea and coast of Kendari City is currently experiencing considerable physical pressure due to land activities. Specifically for Kendari Bay, the silting rate due to sediment intrusion has resulted in an increase in the land area within the bay body. Sedimentation rate in Kendari Bay reaches $110.113,5 \mathrm{~m}^{3}$ /year or 143.148 tons/ year. All land activities will lead to the inside of the Kendari Bay coast of the Kendari bay area. Land clearing in watersheds that flow into bays also plays a role in increasing surface erosion and is a major factor increasing the supply of sediment loads through estuaries to the Gulf. Sedimentation that occurs in Kendari Bay can be characterized by increasingly murky waters especially at locations close to river mouths and land (Subhan \& Afu, 2018).

Sediment contributions come from activities on the pier in the bay area. Nusantara Port which is visited by large-scale vessels at any time, including the stopover of Pelni ships, KM Tilongkabila that serves the eastern region of Sulawesi Island, Ferry Ports crossing from Kendari City-Wawonii Island, Ocean Fishing Ports and Fishing Boat Landing Ports and marine fishing vessel bases private.

Not only causes sedimentation, but the presence of the port causes shipping traffic to be crowded. So that oil spills, paints, rust ship walls can be as water pollutants. Other sources of pollution can be identified from various sources including the fishing industry, public port, fishing port, waste from hotel and shop, household waste, mining, and various other 
activities. This condition does not include sources of pollution arising from activities in all watershed that lead to the Kendari bay. The dense activities of the port, domestic waste and the swelling of wastes carried by the flow of several rivers, it is suspected that the sediment and seawater of Kendari Bay have been polluted by heavy metals such as Mercury $(\mathrm{Hg})$ and Chromium (Cr).

The Environmental Protection Agency (EPA) has determined that mercury and chromium are metals that are carcinogens in humans. Mercury at high exposure can cause permanent damage of the brain, kidney, and fetal. While chromium can cause inflammation of the skin. Long-term exposure can cause damage to the liver, blood circulation, kidneys and nerve tissue, and disorders of the skin (Griswold \& Ph, 2009).

The study, titled Mercury in Marine and Oceanic Waters - a Review, was taken from the Journal of Water Air Soil Pollut, by Barbara Gworek, et al in 2016, explained about mercury in ocean and ocean waters. Mercury contamination in water has become a problem for the environment and human health. In the aquatic environment, mercury occurs in many forms, which depend on the oxidationreduction conditions. The concentration of mercury in marine waters in various parts of the world has been presented. In the relevant literature, two models describing the fate and behavior of mercury in saltwater reservoirs have been presented, a conceptual model that treats all oceans as one ocean and the Bocean margin model, provided that sea margins manifest themselves as the convergence of continents and oceans, which include geological features such as, estuary, inland sea, and continental shelf. These two conceptual models have been summarized in the text. The mercury content in benthic sediments usually reflects the level in the water reservoir, especially in reservoirs located in contaminated areas (mines, metallurgical plants, chemically) (Gworek et al., 2016).

The study, titled Distribution of Heavy Metals in Surface Sediments of the Bay of Bengal Coast was taken from the Journal of Toxicology, by M.Z.H Khan, et al in 2017 about the distribution of heavy metals in sediments on the Coast of Bengal. This study discusses the concentration of main elements $(\mathrm{Si}, \mathrm{Al}, \mathrm{Ca}, \mathrm{Fe}$, and $\mathrm{K}$ ) and minor elements ( $\mathrm{Cd}, \mathrm{Mn}, \mathrm{Ni}, \mathrm{Pb}, \mathrm{U}$, $\mathrm{Zn}, \mathrm{Co}, \mathrm{Cr}, \mathrm{As}, \mathrm{Cu}, \mathrm{Rb}, \mathrm{Sr}$, and $\mathrm{Zr}$ ) in sediments on Bengal Coast. It was revealed that most trace elements had contaminated the Bengal sea waters carried by river flows were also affected by industrial impacts, shipyards, gas production industry, and urban waste. The concentrations of the heavy metals in sediments generally met international sea sediment quality criteria. However, continuous monitoring of the water quality of Bengal Coast needs to be carried out with a view to minimizing the health risks of population and the adverse impacts on the aquatic ecosystem (Khan et al., 2017).

The research is very important to be carried out, considering the effects of heavy metal contamination and still rarely conducted research on mercury and chromium heavy metal contamination in Kendari Bay. Therefore, by considering the many potential sources of heavy metals pollution, the high sedimentation rate in the Kendari Bay, the ecological cycle of heavy metals contamination for marine biota and the carcinogenic efect of heavy metals in humans, the researchers were interested in measuring the concentration of heavy metals Mercury ( $\mathrm{Hg}$ ) and Chromium (Cr) contained in sediments and seawater in Kendari Bay.

\section{Method}

This study used an observational design with a descriptive approach. This study was conducted to determine the content of heavy metals mercury and chromium in seawater and sediments in the waters of Kendari Bay.

The study was conducted in April 2019 in the area of Kendari Bay. The choice of location based on considerations: a) The coastal area has experienced sedimentation and water pollution from several rivers, one of which is the Wanggu River which provides the largest sedimentation contribution. b) Coastal communities consume marine biotas such as various types of fish and shellfish originating from these waters that have been contaminated by heavy metals.

The samples were seawater and sediment of Kendari Bay. The sampling point based on the location of source the entry of pollutants into the sea and each point taken 3 points from each station, namely: 


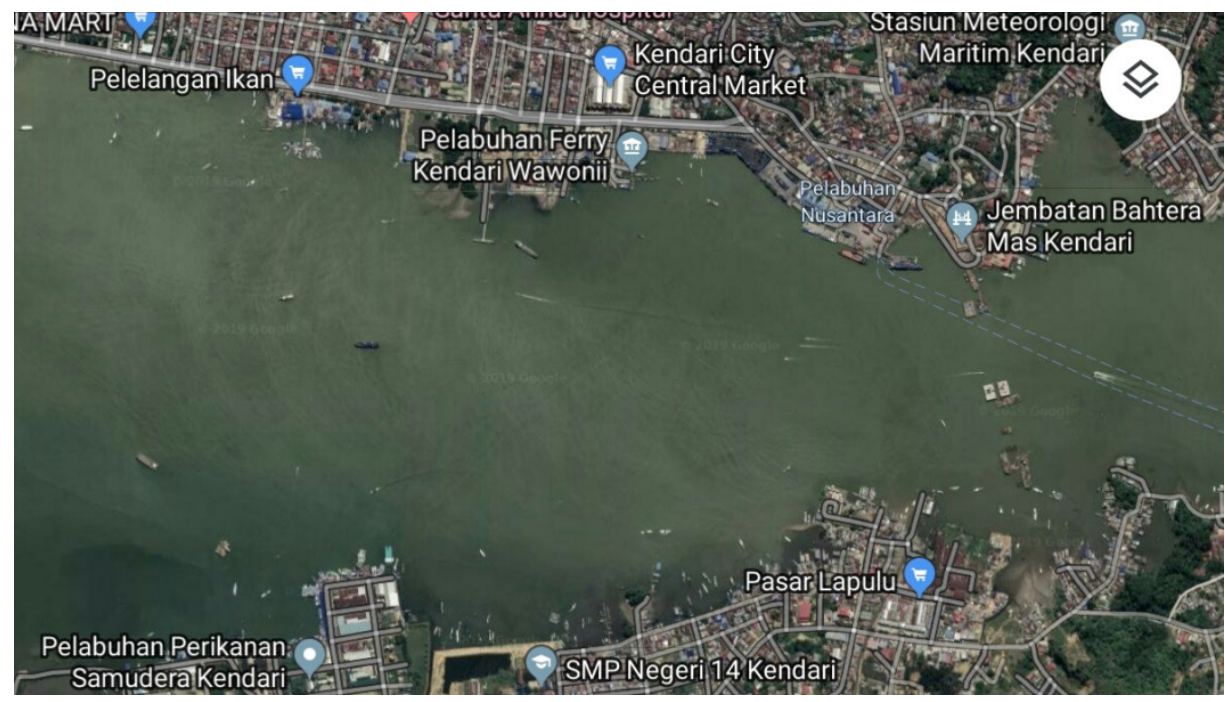

Picture 1. Research Location Map

Station 1: Nusantara Port

Station 2: Kendari-Wawonii Ferry Port

Station 3: Fish Landing Pier

Station 4: Samudera Port

Station 5: Private Marine Fishing Vessels Base

Sampling of sediments and sea water was carried out 2 times ie morning and evening by utilizing volunteer services. Sediment and sea water samples that have been obtained are then brought to Biology Laboratory of Faculty of Mathematics and Natural Sciences Halu Oleo University for analysis of mercury and chromium content using the Atomic Absorbtion Spectrophotometry (AAS) method. Result and Discussion

The quality of the sea and coast of Kendari City is currently experiencing considerable physical stress due to land activities. Specifically for the Kendari Bay, the silting rate due to sediment intrusion has resulted in an increase in the land area within the gulf body. Garbage mixed with sediment has made the permanent plain which covers \pm 25 to 50 ha. Area of Kendari bay in the capital city of Southeast Sulawesi, 3/4 (three quarters) is dominated by the coastal area of the bay which has a very large pollution potential. This is influenced by the form of a semi-closed bay so that all land activities will lead to the inside of the beach of Kendari bay.

Based on the survey that at the five stations (Port / Pier) and 15 sampling points, show high levels of mercury and chromium both in seawater and sediments. On Table 1 , show that the average concentration of mercury in the seawater in Kendari Bay, the highest in area of Fish Landing Pier of 0.0045 $\mathrm{ppm}$ in the morning and $0.0040 \mathrm{ppm}$ in the afternoon. While the lowest in the Nusantara Port of $0.0020 \mathrm{ppm}$ in the morning 0.0017 $\mathrm{ppm}$ in the afternoon. Likewise, for the average concentration of chromium in sea water, the highest in area of Fish Landing Pier of 0.0074 $\mathrm{ppm}$ in the morning and $0.0067 \mathrm{ppm}$ in the afternoon as shown in Table 2. While the lowest was in the Private Marine Fishing Vessels Base of $0,0037 \mathrm{ppm}$ in the morning and 0,0032 ppm in the afternoon.

Table 3 shows the results of survey on sediments. The average concentration of mercury in the sediments was highest in area of Fish Landing Pier of 1.7768 ppm in the morning and $1.5288 \mathrm{ppm}$ in the afternoon. While the lowest in the Nusantara Port of 0.9716 ppm in the morning and $0.9173 \mathrm{ppm}$ in the afternoon. Similarly, the highest chromium in sediment of Kendari Bay was in the Fish Landing Pier of $4,8900 \mathrm{ppm}$ in the morning and 4,7007 ppm in the afternoon as shown in Table 4. While the lowest was at the Private Marine Fishing Vessels Base of $3.4929 \mathrm{ppm}$ in the morning and $3.3234 \mathrm{ppm}$ in the afternoon. 
Table 1. Distribution of Mercury in Sea Water of Kendari Bay

\begin{tabular}{|c|c|c|c|c|c|}
\hline \multirow{2}{*}{ No } & \multirow{2}{*}{ Location } & \multicolumn{2}{|c|}{ Sampling I (Morning) } & \multicolumn{2}{|c|}{ Sampling II (Afternoon) } \\
\hline & & Concentration & Average & Concentration & Average \\
\hline \multirow[t]{4}{*}{1} & Nusantara Port & & & & \\
\hline & Sampling point 1 & 0,0020 & & 0,0016 & \\
\hline & Sampling point 2 & 0,0016 & 0,0020 & 0,0015 & 0,0017 \\
\hline & Sampling point 3 & 0,0024 & & 0,0020 & \\
\hline \multirow[t]{4}{*}{2} & Kendari-Wawonii Ferry Port & & & & \\
\hline & Sampling point 1 & 0,0031 & & 0,0029 & \\
\hline & Sampling point 2 & 0,0027 & 0,0031 & 0,0021 & 0,0027 \\
\hline & Sampling point 3 & 0,0034 & & 0,0031 & \\
\hline \multirow[t]{4}{*}{3} & Fish Landing Pier & & & & \\
\hline & Sampling point 1 & 0,0047 & & 0,0039 & \\
\hline & Sampling point 2 & 0,0042 & 0,0045 & 0,0039 & 0,0040 \\
\hline & Sampling point 3 & 0,0045 & & 0,0041 & \\
\hline \multirow[t]{4}{*}{4} & Samudera Port & & & & \\
\hline & Sampling point 1 & 0,0025 & & 0,0019 & \\
\hline & Sampling point 2 & 0,0022 & 0,0021 & 0,0018 & 0,0016 \\
\hline & Sampling point 3 & 0,0016 & & 0,0012 & \\
\hline \multirow[t]{4}{*}{5} & Private Marine Fishing Vessels Base & & & & \\
\hline & Sampling point 1 & 0,0018 & & 0,0017 & \\
\hline & Sampling point 2 & 0,0022 & 0,0022 & 0,0021 & 0,0020 \\
\hline & Sampling point 3 & 0,0025 & & 0,0022 & \\
\hline
\end{tabular}

Source: Pimary Data, 2019

\section{Table 2. Distribution of Chromium in Sea Water of Kendari Bay}

\begin{tabular}{|c|c|c|c|c|c|}
\hline \multirow{2}{*}{ No } & \multirow{2}{*}{ Location } & \multicolumn{2}{|c|}{ Sampling I (Morning) } & \multicolumn{2}{|c|}{ Sampling II (Afternoon) } \\
\hline & & Concentration & Average & Concentration & Average \\
\hline \multirow[t]{4}{*}{1} & Nusantara Port & & & & \\
\hline & Sampling point 1 & 0,0048 & & 0,0038 & \\
\hline & Sampling point 2 & 0,0052 & 0,0052 & 0,0049 & 0,0047 \\
\hline & Sampling point 3 & 0,0057 & & 0,0054 & \\
\hline \multirow[t]{4}{*}{2} & Kendari-Wawonii Ferry Port & & & & \\
\hline & Sampling point 1 & 0,0055 & & 0,0052 & \\
\hline & Sampling point 2 & 0,0060 & 0,0055 & 0,0057 & 0,0052 \\
\hline & Sampling point 3 & 0,0050 & & 0,0046 & \\
\hline \multirow[t]{4}{*}{3} & Fish Landing Pier & & & & \\
\hline & Sampling point 1 & 0,0078 & & 0,0071 & \\
\hline & Sampling point 2 & 0,0067 & 0,0074 & 0,0062 & 0,0067 \\
\hline & Sampling point 3 & 0,0077 & & 0,0069 & \\
\hline \multirow[t]{4}{*}{4} & Samudera Port & & & & \\
\hline & Sampling point 1 & 0,0040 & & 0,0037 & \\
\hline & Sampling point 2 & 0,0043 & 0,0040 & 0,0036 & 0,0036 \\
\hline & Sampling point 3 & 0,0038 & & 0,0034 & \\
\hline \multirow[t]{4}{*}{5} & Private Marine Fishing Vessels Base & & & & \\
\hline & Sampling point 1 & 0,0033 & & 0,0028 & \\
\hline & Sampling point 2 & 0,0037 & 0,0037 & 0,0032 & 0,0032 \\
\hline & Sampling point 3 & 0,0042 & & 0,0036 & \\
\hline
\end{tabular}

Source: Pimary Data, 2019 
Table 3. Distribution of Mercury in Sediment of Kendari Bay

\begin{tabular}{|c|c|c|c|c|c|}
\hline \multirow{2}{*}{ No } & \multirow{2}{*}{ Location } & \multicolumn{2}{|c|}{ Sampling I (Morning) } & \multicolumn{2}{|c|}{ Sampling II (Afternoon) } \\
\hline & & Concentration & Average & Concentration & Average \\
\hline \multirow[t]{4}{*}{1} & Nusantara Port & & & & \\
\hline & Sampling point 1 & 0,9388 & & 0,8934 & \\
\hline & Sampling point 2 & 0,9478 & 0,9716 & 0,9023 & 0,9173 \\
\hline & Sampling point 3 & 1,0283 & & 0,9562 & \\
\hline \multirow[t]{4}{*}{2} & Kendari-Wawonii Ferry Port & & & & \\
\hline & Sampling point 1 & 1,5547 & & 1,3870 & \\
\hline & Sampling point 2 & 1,4541 & 1,5316 & 1,1966 & 1,3302 \\
\hline & Sampling point 3 & 1,5861 & & 1,4070 & \\
\hline \multirow[t]{4}{*}{3} & Fish Landing Pier & & & & \\
\hline & Sampling point 1 & 1,6953 & & 1,4682 & \\
\hline & Sampling point 2 & 1,7644 & 1,7768 & 1,4956 & 1,5288 \\
\hline & Sampling point 3 & 1,8708 & & 1,6227 & \\
\hline \multirow[t]{4}{*}{4} & Samudera Port & & & & \\
\hline & Sampling point 1 & 1,1564 & & 1,0987 & \\
\hline & Sampling point 2 & 1,0732 & 1,1407 & 0,9681 & 1,0204 \\
\hline & Sampling point 3 & 1,1924 & & 0,9943 & \\
\hline \multirow[t]{4}{*}{5} & Private Marine Fishing Vessels Base & & & & \\
\hline & Sampling point 1 & 1,2055 & & 1,0206 & \\
\hline & Sampling point 2 & 1,2768 & 1,1991 & 1,1370 & 1,0503 \\
\hline & Sampling point 3 & 1,1149 & & 0,9934 & \\
\hline
\end{tabular}

Source: Pimary Data, 2019

Table 4. Distribution of Chromium in Sediment of Kendari Bay

\begin{tabular}{|c|c|c|c|c|c|}
\hline \multirow{2}{*}{ No } & \multirow{2}{*}{ Location } & \multicolumn{2}{|c|}{ Sampling I (Morning) } & \multicolumn{2}{|c|}{ Sampling II (Afternoon) } \\
\hline & & Concentration & Average & Concentration & Average \\
\hline \multirow[t]{4}{*}{1} & Nusantara Port & & & & \\
\hline & Sampling point 1 & 4,3426 & & 4,2071 & \\
\hline & Sampling point 2 & 4,5827 & 4,4516 & 4,4180 & 4,3202 \\
\hline & Sampling point 3 & 4,4295 & & 4,3356 & \\
\hline \multirow[t]{4}{*}{2} & Kendari-Wawonii Ferry Port & & & & \\
\hline & Sampling point 1 & 4,0783 & & 3,9858 & \\
\hline & Sampling point 2 & 4,2837 & 4,1929 & 4,0877 & 4,0172 \\
\hline & Sampling point 3 & 4,2168 & & 3,9782 & \\
\hline \multirow[t]{4}{*}{3} & Fish Landing Pier & & & & \\
\hline & Sampling point 1 & 4,9268 & & 4,6829 & \\
\hline & Sampling point 2 & 4,9958 & 4,8900 & 4,8258 & 4,7007 \\
\hline & Sampling point 3 & 4,7475 & & 4,5933 & \\
\hline \multirow[t]{4}{*}{4} & Samudera Port & & & & \\
\hline & Sampling point 1 & 3,6714 & & 3,5762 & \\
\hline & Sampling point 2 & 3,9684 & 3,8317 & 3,9024 & 3,7518 \\
\hline & Sampling point 3 & 3,8552 & & 3,7768 & \\
\hline \multirow[t]{4}{*}{5} & Private Marine Fishing Vessels Base & & & & \\
\hline & Sampling point 1 & 3,3791 & & 3,2854 & \\
\hline & Sampling point 2 & 3,4603 & 3,4929 & 3,2067 & 3,3234 \\
\hline & Sampling point 3 & 3,6394 & & 3,4781 & \\
\hline
\end{tabular}

Source: Pimary Data, 2019 
The survey showed that all sampling points at five Ports / Piers were contaminated with mercury and chromium in seawater and sediments. Based on the Minister of the Environment Decree No. 51/ 2004, that standard quality of seawater for mercury of $0.001 \mathrm{ppm}$ while for chromium of $0.005 \mathrm{ppm}$. When compared with the survey, it can be stated that the sea waters of Kendari Bay have been polluted by heavy metals mercury and chromium. This is evidenced from all samples at all sampling points showed concentrations that exceed from standard values of the two types of heavy metals.

The highest levels of mercury and chromium in seawater and sediments are found in the Fish Landing Pier area. This is due to the dense traffic activity of fishing vessels, there are also Pertamina refueling the ships. Dense settlements, hospitals and hotels also contribute where waste is directly channeled into the bay. Paints on ships, fuel oil spills, and some shipwrecks also contribute to the high contamination of heavy metals.

In the general area of Kendari Bay also polluted due to activities throughout the watershed which empties into the Kendari Bay. Coupled with the conditions of sedimentation or siltation of the bay so that it directs the Government to make several Piers for tourism destination. We can see many tourist boats are docked.

The construction of the Bahteramas Bridge or Kendari Bay Bridge that connects Old City with Poasia District is also one of the contributors to heavy metal contamination. The construction process which involves heavy equipment that floats above the sea within a period of 3 years certainly discharges its waste directly into the sea.

Besides that, along the seafront of Kendari Bay which has been designed as an entertainment place also contributes to pollution. The seafront of Kendari Bay is still a favorite area of tourist that must be visited by both locals and migrants. The hectic activity of visitors every day certainly be the cause of the high generation of garbage thrown away into the sea. Still lacking public awareness about waste. Inorganic waste such as plastic of food packaging or drinks very visible on the surface of the sea.

In the same in a study, where levels of the heavy metals were determined in coastal water, sediment and soft tissues of the Saccostrea cucullata, from the intertidal zona at five stations in the Gulf of Chabbar on the Iraniai coasts along the Oman Sea. Based on this research, land based activities; shipping activity and sewage disposal from the vessel and residential areas close to these harbors are the main source of metal pollution in the Gulf of Chabbar (Bazzi, 2014).

Water pollution by heavy metals is a worldwide problem caused by bioaccumulation and biomagnification in the food chain and the toxicity of these heavy metal elements. Contamination of sediment with heavy metals is an important environmental problem that has negative consequences for aquatic organisms and human health. Sediment acts as a primary collector of metals in the aquatic environment. Quality of sediment shows the status of water pollution (Ali et al., 2019).

Heavy metals pollution in water bodies has become a major water quality issue in many fast-growing cities over the last few decades (Akoto, 2008). This is because heavy metals pose threats to public water supplies (Terra, 2007) and can also cause health hazards to human consumption of fish and water resources (Akoto, 2014). Today, water pollution is one of the environmental and health issues, especially in areas around rivers (Musfirah \& Rangkuti, 2019)hospitals, domestic, and agriculture. The contamination status on the Code River according to BLH Yogyakarta reported in 2014 was heavily polluted based on STORET $(\leq-31$

Heavy metals contribute to the part of the earth crust, heavy metals such as $\mathrm{Cu}, \mathrm{Pb}$, $\mathrm{Cr}$, and $\mathrm{Hg}$, are non-nutritive toxic metals and are environmental pollutants. Agricultural activities through the application of phosphate fertilizers make this toxic metal readily available in the soil, which can leach in the spring aquifer. Even in traces, these elements can pose a severe risk in the environment, and their bioaccumulation in the food chain can cause a drastic problem to humans, this is as a result of the accumulation of metals in plant parts having secondary metabolites, which is responsible for a particular pharmacological 
activity (Vaidyanathan et al., 2016).

Heavy metals present in water bodies will experience sedimentation and accumulation in sediments. The metal can also accumulate in the body of biota in the waters (including sessile macrozoobenthos), either diffusively or through the food chain and will eventually reach humans. This phenomenon is known as bioaccumulation or biomagnification (Emmanuel et al., 2018).

Bioaccumulation of heavy metals does not only depend on the organs, but also on the interactions between metals and the target organs (Nanda, 2014). Fishes bioaccumulate heavy metals and thus act as good bioindicators of pollution (Ibemenuga, 2013). The observed variability in the concentration of heavy metals in the three fish species T. zillii, M. electricus and C. gariepinus is a reflection of varying degrees of metal thresholds in the animals. Aquatic organisms concentrate metal from water and food either by absorption or ingestion. The levels of metal accumulated vary from organ to organ in fish species (Ibemenuga et al., 2019).

This can be seen in a study, where the result shows that the mercury content in belanak network is $0.143-0.188 \mathrm{ppm}$, sediment 2.453 $2.800 \mathrm{ppm}$ and the seawater $0.030-0.040 \mathrm{ppm}$. Based on the decision of the state minister of environmental Number: Kep-51/2004 about The Guidelines for Determination of $\mathrm{Hg}$ Standard Quality for seawater is $0.002 \mathrm{ppm}$ and $0.001 \mathrm{ppm}$ for marine biota. It shows that the Palu bay water condition has been polluted and the belanak is not worth to be consumed (Yusuf \& Hamzah, 2013).

In another study, the concentration of heavy and toxic metals $\mathrm{Cu}, \mathrm{Zn}, \mathrm{Cd}, \mathrm{Pb}$, and $\mathrm{Hg}$ were determined in the liver and muscles of Rutilus frisii kutum and their relationships with growth parameters (length, age, condition factor) and hepatosomatic index were examined. Thirty-six fish samples were collected from February through March 2009 caught by beach seine in the southwest parts of the Caspian Sea. Atomic absorption and $\mathrm{Hg}$ determined concentrations of $\mathrm{Cd}, \mathrm{Pb}, \mathrm{Zn}$, and $\mathrm{Cu}$ by vapor method. Cadmium was recorded only in liver samples. Range of other metals in muscle tissue were ND -0.591, 0.001-0.013, 11- 26 and 0.729 -7.261 $\mu$ g.g- $1 \mathrm{dw}$ for $\mathrm{Pb}, \mathrm{Hg}$,
$\mathrm{Zn}$, and $\mathrm{Cu}$ respectively. The highest levels of $\mathrm{Pb}, \mathrm{Zn}$, and $\mathrm{Cu}$ were recorded in muscles $\mathrm{Hg}$ and $\mathrm{Cd}$ in liver samples. Growth parameters showed a significant relationship with $\mathrm{Zn}$ and $\mathrm{Cd}$ the concentrations in the liver samples and only $\mathrm{Zn}$ concentrations in muscle samples. There was a positive significant correlation between concentration of $\mathrm{Cd}$ in liver and physiological indices $(p<0.05)$. Although higher concentration of $\mathrm{Pb}$ was recorded in this study in comparison to previous studies, based on Provisional Tolerable Weekly and daily Intake of fish for human health, kutum is considered safe for human consumption. Considering the results of this study it seems the reproductive status of the fish influences heavy metals concentration in liver and muscles of kutum and therefore concentrations of some metals such as $\mathrm{Zn}$ and $\mathrm{Cu}$ in the liver samples may not be a reliable bioindicator for environmental pollution (Monsefrad et al., 2012).

Subsequent research also showed the presence of heavy metals in fish bodies. The analysis of heavy metals showed the presence of $\mathrm{Hg}, \mathrm{Cd}, \mathrm{Zn}, \mathrm{Cr}$, and $\mathrm{Pb}$ in the spleen, liver, and muscle of all analyzed samples (Fig. 2). The livers showed higher levels of contamination for $\mathrm{Cd}$ and $\mathrm{Zn}$, while the spleens showed higher levels of $\mathrm{Cr}$ (Fig. 2). It is also important to highlight that levels of $\mathrm{Hg}$ and $\mathrm{Pb}$ were higher or similar in muscle tissue compared to the liver and spleen (Arantes et al., 2016).

So based on ecological influence, mercury and chromium have a high risk ecological to the surrounding aquatic environment, meaning that the presence of mercury and chromium in sediments clearly affects biota or other organisms in the waters. Many studies showed that the content of heavy metals in sediments always higher than in water and marine biota. This is because heavy metals have a tendency to be suspended at the bottom of the water.

In nature, mercury $(\mathrm{Hg})$ is found in the elemental form of mercury $\left(\mathrm{Hg}^{0}\right)$, monovalent mercury $\left(\mathrm{Hg}^{+1}\right)$, and bivalent $\left(\mathrm{Hg}^{+2}\right)$. When entering into waters, mercury binds easily to the chlorine present in seawater and forms $\mathrm{HgCl}$ bonds. In this form, $\mathrm{Hg}$ easily enters plankton and can move to another marine biota. Inorganic mercury $(\mathrm{HgCl})$ will be turned into organic mercury (metal mercury) by the 
role of microorganisms that occur in sediments at the bottom of the water. Mercury can also be combined with carbon to form organomercury compounds. The most common organo-mercury compound is metal mercury produced by microorganisms in water and soil. The microorganisms are then consumed by the fish so that the concentration of mercury in the fish increases (Widowati, 2008).

The hygienic risk of mercury in the waters of rivers, lakes, and seas is based on the biotransformation of inorganic mercury to methyl compounds which are very toxic. The mercury is especially present, in fish, which become a risk factor for humans, animals, and birds. Specifically, the anaerobic microorganisms, which occur naturally in sediments of the seabed and of the bottoms of lakes, have the ability to methylate inorganic mercury compounds, a process that has a key role in the mercury cycle of the food chain of aquatic organisms. The occurrence of mercury in fish, and thus in their products, is significant. Fish are the final link in the food chain in the aquatic environment. Fish are the major source of food in several countries, and consequently, the major source of mercury in the diet. Inorganic mercury can convert to organic in the digestive tract of fish. Mercury is fixed in almost all the organs and tissues of fish, whereby the mercury is practically not released from the body of the fish. The main form of mercury in fish is methylmercury (Kimáková et al., 2018).

Similarly, chromium can come into all strata of environment, whether in the strata of water, soil or air (atmospheric layer). Chromium that enters the environment strata can come from a variety of sources. But the most common and presumed sources of Chromium input into environmental strata are from industrial activities, household activities, combustion and fuel mobilization (Widowati, 2008).

Heavy metals concentrations above the threshold can have adverse effects on biota up to humans. Heavy metals in biota with high concentrations have a negative effect on the ecological health of aquatic animals and can contribute to population decline. Heavy metals are neurotoxins in fish species. The interaction of heavy metals with chemical stimuli in fish might interfere with fish's communication with the environment. There have been many findings where heavy metals have an effect body abnormalitiy on fish. In general, these deformities have a negative effect on fish populations because body defects on fish affect the survival, growth, and welfare. Abnormalities on fish function as biomarkers from environments that have been contaminated with heavy metals (Ali et al., 2019).

Heavy metals, such as mercury, cadmium, copper, lead, and zinc are of the most important pollutants which affect aquatic environment and fish. They are extremely dangerous for the health of fish. Most of these metals are characterized by being accumulated in tissues and lead to the poisoning of fish. These metals can effectively influence the vital operations and reproduction of fish; weaken the immune system, and induce pathological changes. As such, fish are used as bio-indictors, playing an important role in monitoring heavy metals pollution (Authman, 2015).

Heavy metals enter into various environmental matrices (air, water, and soil) from a wide variety of natural and anthropogenic sources. All the sources of pollution affect the physicochemical characteristics of the water and biological components and thus the quality and quantity of fish. Fishes are one of the most widely distributed organisms in the aquatic environment and, being susceptible to heavy metal contamination (Khillare et al., 2017). As a result, large scale mortality of fishes has been observed due to the discharge of heavy metals in natural water resources (FAO, 1996). Catfish Heteropneustes fossilis, which is an annual breeder and breeds during the monsoon rainfall (July-August). The fish is economically important for aquaculture in the Indian subcontinent and the flesh is highly priced, which is rich in protein but poor in lipid and fat content. At Varanasi due to heavy pollution in Ganges River and anthropogenic activities, river water is contaminated by heavy metal pollutants, which has a severe impact on survivability of aquatic organisms especially fish population (Gautam \& Chaube, 2018).

The toxic effects of heavy metals can affect the individual growth rates, physiological functions, mortality and reproduction in fish. 
Heavy metals entre in fish bodies in three possible ways: by gills, by digestive track and body surface. The gills are considered as the significant site for direct uptake of metals from the water, though the body surface is normally estimated to take the minor part in the uptake of heavy metals in fish. Heavy metal accumulation can also be caused by the food source, possibly leading to bio-magnification, the augmentation of toxins up the food chain (Afshan et al., 2014) zinc $(\mathrm{Zn}$

Various research studies indicated that chromium exerts its toxicity across various fish species at different functional levels. Different species of fish namely dace, perch, stickleback, roach and rainbow trout was investigated for $\mathrm{Cr}$ (VI) sensitivity and it was found that even at minute concentration rainbow trout is 1.16 to 2.52 times more sensitive as compared to other test species. The root cause of fatality is multiple and depends on timeconcentration combinations. When fish is initially encountered to chromium it undergoes various behavioral modifications like suspending feeding behavior, uneven swimming and accelerated operculum. It may trigger structural changes such as hypertrophy and paraplegia at gill epithelium and weakens the body's immune system. In another study after exposure to hexavalent chromium modification in behavioral patterns of Channa punctatus was studied. The exposed fish showed irregular swimming and became sluggish. The changes in gills were illustrated by epithelial hyperplasia, edema, epithelial lifting and necrosis (Aslam \& Yousafzai, 2017).

The toxicity of trace metals has long been a concern, considering they are not removed from aquatic ecosystems by self-purification and accumulate in suspended particulates and sediments, thereby potentially threatening human health and ecosystems via the food web. Consequently, evaluating the ecological risk from trace elements has become a hot topic (Arantes et al., 2016).
EPA has determined mercury chloride and methylmercury as carcinogenic compounds in humans. The nervous system is very sensitive to all forms of mercury compounds. High levels of exposure can cause permanent damage to the brain, kidneys, and fetal development. Effects on brain function can cause irritability, shame, tremors, changes in vision and hearing, as well as memory problems. Short-term exposure to high levels of mercury vapor can cause lung damage, nausea, vomiting, diarrhea, increased blood pressure or heart rate, skin rashes, and eye irritation. Besides that, mercury is determined as neurotoxicant. Outbreaks of methylmercury poisoning have been clearly demonstrated that adults, children and developing fetuses are very at risk from mercury exposure. When mothers with symptoms of nervous system damage give birth to babies with severe disabilities, it becomes clear that the development of the nervous system of the fetus is more susceptible to methylmercury than the nervous system of adults (Griswold \& Ph, 2009).

Toxicity of Mercury in humans are distinguished according to the form of $\mathrm{Hg}$ compounds, namely inorganic and organic. $\mathrm{Hg}$ inorganic poisoning is characterized by symptoms of tremor in adults, then continues with tremors in the facial muscles, which then spread to the fingers and hands. When poisoning continues tremors occur on the tongue, stammering, walking looks stiff and lost balance. In addition to the toxicity of inorganic $\mathrm{Hg}$, this form of organic $\mathrm{Hg}$ also causes very dangerous toxicity, an example of a case toxicity of methyl mercury is a case of "Minamata disease" which afflicts both adults and young children that occur in Japan (Widowati, 2008).

Hehasaseries of chemicaltransformations in the environment, appearing as zero oxidation state $(\mathrm{Hg})$, mercurous state $(\mathrm{Hg}+)$, and mercuric state $(\mathrm{Hg})$; additionally, it may form organic compounds, being methylmercury ( $\mathrm{MeHg}$ ), the most important form in terms of toxicity and effects on health. MeHg causes damages at the central nervous system level and its neurotoxic effect is attributed to mitochondrial damage via glutathione reduction (GSH), which reduces ATP synthesis and increases lipid, protein, and DNA peroxidation; $\mathrm{MeHg}$, due to its high affinity with the sulfhydryl group, it forms complexes 
with $\mathrm{N}$-acetylcysteine and cysteine, important precursors of GSH, which Increases free radical production and reduces the oxidation defense systems and the imbalance between both processes produces the uncontrolled release of calcium from the mitochondrion, disturbing intracellular calcium levels.

The toxicological profile of $\mathrm{Hg}$ varies depending on its form. Exposure to $\mathrm{Hg} 0$ and $\mathrm{MeHg}$ produce symptoms in the central nervous system, while $\mathrm{Hg}$ mono and divalent forms act mainly in the kidney. $\mathrm{MeHg}$ corresponds to the most toxic organic form of $\mathrm{Hg}$. It is neurotoxic due to its accumulation in the central nervous system, deteriorating physiological Functions through the interruption of the endocrine glands. $\mathrm{MeHg}$ is classified as carcinogenic for humans, group $2 \mathrm{~B}$, mainly related to liver and esophagus cancer. In addition, Methylmercury can cross the placenta causing neurotoxic effects during human brain development, probably permanent (Zuluaga Rodríguez et al., 2015).

Such as chromium (VI) is a toxic compound, while chromium (III) is an important nutrient in humans. High levels of exposure can cause nasal irritation, nasal ulcers, colds, and respiratory problems such as asthma, coughing, and shortness of breath. While longterm exposure can cause damage to the liver, blood circulation, kidneys and nerve tissue, and disorders of the skin (Griswold \& Ph, 2009).

Acute toxicity of Chromium through the digestive tract can cause renal tubular necrosis. Workers in the workplace of the chrome industry show high levels of Chromium in the blood, especially in red blood cells. Digesting foods that contain high levels of Cr (VI) can cause indigestion, in the form of stomach pain, vomiting and bleeding, stomach ulcers, convulsions, kidney damage, and liver, and can even cause death (Widowati, 2008).

Due to extensive damage caused by heavy metal poisoning on various organs of the body, the investigation and identification of therapeutic methods for poisoning with heavy metals are very important. The most common method for the removal of heavy metals from the body is the administration of chemical chelators. Recently, medicinal herbs have attracted the attention of researchers as the potential treatments for heavy metals poisoning because of their fewer side effects. A study had review the potential of medicinal herbs such as Allium sativum (garlic), Silybum marianum (milk thistle), Coriandrum sativum (cilantro), Ginkgo biloba (ginkgo), Curcuma longa (turmeric), phytochelatins, triphala, herbal fibers and Chlorophyta (green algae) to treat heavy metal poisoning (Mehrandish et al., 2019).

\section{Conclusion}

All sampling points at five Ports/ Piers were contaminated with mercury and chromium in seawater and sediments. Based on the Minister of the Environment Decree No. 51/2004, that standard quality of seawater for mercury of $0.001 \mathrm{ppm}$ while for chromium of $0.005 \mathrm{ppm}$. When compared with the survey, it can be stated that the sea waters of Kendari Bay have been polluted by heavy metals mercury and chromium. This is evidenced from all samples at all sampling points showed concentrations that exceed from standard values of the two types of heavy metals.

The highest levels of mercury and chromium in seawater and sediments are found in the Fish Landing Pier (TPI) area. This is caused by the dense traffic activities of fishing vessels, there are also Pertamina refueling the ships, residential waste, hospital waste, hospitality waste, tourism waste, paints on ships, oil spills, rust from shipwrecks, as well as heavy equipment activities from the construction of the Bahteramas Bridge or Kendari Bay Bridge that connects Old City with Poasia District, are also as a contributor to heavy metals contamination.

Technology needs to control heavy metal contamination as well as policies and law enforcement regarding activities at the sea that have the potential to pollute waters.

\section{Acknowledgement}

Thank you to DRPM Kemenristek Dikti for facilitating this research through grants, as well as all parties who could not be mentioned one by one who were heavily involved in this research.

\section{References}

Afshan, S., Ali, S., Ameen, U., Farid, M., Bharwana, 
S., Hannan, F., \& Ahmad, R. (2014). Effect of Different Heavy Metal Pollution on Fish. Research Journal of Chemical and Environmental Sciences, 2, 74-79.

Ali, H., Khan, E., \& Ilahi, I. (2019). Environmental chemistry and ecotoxicology of hazardous heavy metals: Environmental persistence, toxicity, and bioaccumulation. Journal of Chemistry, 2019(Cd). https://doi. org/10.1155/2019/6730305

Arantes, F. P., Savassi, L. A., Santos, H. B., Gomes, M. V. T., \& Bazzoli, N. (2016). Bioaccumulation of mercury, cadmium, zinc, chromium, and lead in muscle, liver, and spleen tissues of a large commercially valuable catfish species from Brazil. Anais Da Academia Brasileira de Ciencias, 88(1), 137-147. https://doi. org/10.1590/0001-3765201620140434

Aslam, S., \& Yousafzai, A. M. (2017). Chromium toxicity in fish: A review article. Journal of Entomology and Zoology Studies, 5(3), 1483-1488. http://www.entomoljournal. com/archives / 2017 / vol 5 is sue 3 / PartU/5-3-168-230.pdf

Authman, M. M. (2015). Use of Fish as Bioindicator of the Effects of Heavy Metals Pollution. Journal of Aquaculture Research \& Development, 06(04). https://doi. org/10.4172/2155-9546.1000328

Bazzi, A. O. (2014). Heavy metals in seawater, sediments and marine organisms in the Gulf of Chabahar, Oman Sea. Journal of Oceanography and Marine Science, 5(3), 2029. https://doi.org/10.5897/joms2014.0110

Emmanuel, E., Sombo, T., \& Ugwanyi, J. (2018). Assessment of Heavy Metals Concentration in Shore Sediments from the Bank of River Benue, North-Central Nigeria. Journal of Geoscience and Environment Protection, 06(04), 35-48. https://doi.org/10.4236/ gep.2018.64003

Gautam, G. J., \& Chaube, R. (2018). Differential Effects of Heavy Metals (Cadmium, Cobalt, Lead and Mercury) on Oocyte Maturation and Ovulation of the Catfish Heteropneustes fossilis: an In Vitro Study. Turkish Journal of Fisheries and Aquatic Sciences, 18, 12051214.

Griswold, W., \& Ph, D. (2009). Human Health Effects of Heavy Metals. 1-6.

Gworek, B., Bemowska-Kałabun, O., Kijeńska, M., \& Wrzosek-Jakubowska, J. (2016). Mercury in Marine and Oceanic Waters-a Review. Water, Air, and Soil Pollution, 227(10). https://doi.org/10.1007/s11270-016-3060-3

Ibemenuga, K. N., Ezike, F. A., Nwosu, M. C.,
Anyaegbunam, L. C., Okoye, E. I., \& Eyo, J. E. (2019). Bioaccumulation of Some Heavy Metals in Some Organs of Three Selected Fish of Commercial Importance from Niger River, Onitsha Shelf, Anambra State, Nigeria. Journal of FisheriesSciences. Com, 13(3), $1-12$.

Khan, M. Z. H., Hasan, M. R., Khan, M., Aktar, S., \& Fatema, K. (2017). Distribution of heavy metals in surface sediments of the bay of Bengal coast. Journal of Toxicology, 2017. https://doi.org/10.1155/2017/9235764

Kimáková, T., Kuzmová, L., Nevolná, Z., \& Bencko, V. (2018). Fish and fish products as risk factors of mercurexposure. Annals of Agricultural and Environmental Medicine, 25(3), 488-493. https://doi.org/10.26444/aaem/84934

Mehrandish, R., Rahimian, A., \& Shahriary, A. (2019). Heavy metals detoxification: A review of herbal compounds for chelation therapy in heavy metals toxicity. Journal of HerbMed Pharmacology, 8(2), 69-77. https:// doi.org/10.15171/jhp.2019.12

Monsefrad, F., Imanpour Namin, J., \& Heidary, S. (2012). Concentration of heavy and toxic metals $\mathrm{Cu}, \mathrm{Zn}, \mathrm{Cd}, \mathrm{Pb}$ and $\mathrm{Hg}$ in liver and muscles of Rutilus frisii kutum during spawning season with respect to growth parameters. Iranian Journal of Fisheries Sciences, 11(4), 825-839.

Musfirah, \& Rangkuti, A. (2019). The Lead Exposure Risk Due to Wells Water Consumption in Code Riverside Community, Yogyakarta City. Jurnal Kesehatan Masyarakat (KEMAS), 14(3), 318-325.

Subhan, S., \& Afu, L. O. A. (2018). Pengaruh Laju Sedimentasi Terhadap Rekrutmen Karang Di Teluk Kendari (The effect of sedimentation rate on coral recruitment in Kendari Bay). Jurnal Manusia Dan Lingkungan, 24(2), 73. https://doi.org/10.22146/jml.23070

Vaidyanathan, K., Vasudevan, D., S, S., \& Vaidyanathan, K. (2016). Environmental Pollution and Heavy Metal Poisons. Textbook of Biochemistry for Medical Students, 5(5), 531-531. https://doi.org/10.5005/jp/ books/13014_38

Widowati, W. (2008). Efek Toksik Logam. Penerbit Andi.

Yusuf, M., \& Hamzah, B. (2013). Kandungan merkuri (Hg) dalam air laut, sedimen, dan jaringan ikan belanak (Liza melinoptera) di perairan Teluk Palu. Yusuf, Mohammad Hamzah, Bharuddin Rahman, Nirdin, 2(3), 140-145.

Zuluaga Rodríguez, J., Gallego Ríos, S. E., \& Ramírez 
Botero, C. M. (2015). Content of Hg, Cd, Pb and as in fish species: a review. Revista Vitae,
22(2), 148-159. https://doi.org/10.17533/ udea.vitae.v22n2a09 